\title{
Students Who are Active in Organizations: Implications for Self-Esteem with Social Loafing
}

\author{
Nadya Zhafira Herda Putri ${ }^{1}$ Fransisca Iriani Roesmala Dewi ${ }^{1 *}$
}

\author{
${ }^{1}$ Faculty of Psychology, Universitas Tarumanagara, Jl. Letjen S. Parman No. 1, West Jakarta 11440, Indonesia. \\ *Corresponding author.Email: fransiscar@fpsi.untar.ac.id
}

\begin{abstract}
Self-development facilities for students to live in society, including by participating in activities or being active in organizations. Interaction in organizations increases individual expectations of the ability of other members to complete work and carry out tasks collectively. Some students are not responsible when given assignments together and do not contribute to the group. When individuals reduce their effort while working with other people, it is called social loafing. This study aims to determine the relationship between selfesteem and social loafing in college students actively organize. This research involved 407 students who are currently active in the management of the organization or committee of the organization. The sampling technique used was purposive sampling. Measurement of self-esteem variables with the Rosenberg SelfEsteem scale and the social loafing scale for social loafing variables. Based on the results of calculations using the Spearman rho, the value of $r=-0.307$ was obtained, $p=0.000<0.05$. There is a significant negative relationship with self-esteem and social loafing among students who are active in organizations. Another finding is that there is no difference in the self-esteem of students who are active in organizations based on gender, position and tenure of management / position. Neither is it found differences in social loafing in terms of position. However, there are significant differences in tenure of management / office.
\end{abstract}

Keywords: Self-esteem, Social Loafing, Students

\section{INTRODUCTION}

Students are social beings who can not live without the other. Social motivation in students encourages them to interact with other individuals [1]. One means of selfdevelopment for students to live in society is by participating in activities or being active in organizations. Organizational activities, this aim to train students in solving a problem, and gain knowledge that is not obtained in lectures [2].

According to Luthan [3], interactions in organizations increased expectations of individuals for the ability of other members to complete work and responsibilities together. Interaction within an organization can lead to the idea that some students are not responsible when given assignments together, do not contribute to groups, and reduce their effort when working with others. In a psychological perspective this is known as social loafing. Social Loafing according to Baron \& Byrne [4] is a decrease in motivation and effort when individuals work in groups, compared to when working individually. According to Setyawan [5], social loafing has a bad impact on an organization or group, because it can reduce performance. This is in line with the statements of Pratama and Wulanyani [6] which state that social loafing is a tendency to give minimal effort towards the achievement of a group. With social loafing, it will be detrimental to other group members because there is an imbalance between the contribution made to individuals and the results obtained by individuals. According to Rahman, the contribution of each individual is highly expected by group members and within the organization. However, not a few of the group members tend to spend less effort when working in groups. However, if the organization can exercise a strong oversight, it can see individual efforts, and it will be beneficial for the organization if individuals ensure the contribution of their members to a group. In addition, individual contributions to a group will increase self-esteem [7].

According to Chidambaram \& Tung [8] there are two aspects to social loafing, namely the dilution effect where individuals are less motivated because they feel their contributions are meaningless or realize that the rewards given to each individual for groups are not the result of their work, and the immediacy gap is that individuals feel alienated from group. This shows, the further away the individual is from the group, the farther away the task is to him. Research conducted by Webb 1997, states that, one of the causes that can influence students to do social loafing is the fear of showing that the individual does not understand the material or lacks assertiveness in the 
individual. The cause of the occurrence of social loafing in the process of doing group assignments is that there are students who feel that they are seniors so they do not want to participate in working on them and only ride names. Then, they are busy so they cannot be left behind, do not know what to do because they do not pay attention to the time the explanation is taking place and do not enter the division of tasks, so it is necessary to explain what tasks must be done [2].

According to Sarwono [9], there are several factors that influence social loafing, one of which is self-esteem, someone who has low self-esteem, so the presence of other people will reduce achievement. Self-esteem is a selfevaluation made by each individual, and people's attitudes towards themselves are from positive to negative attitudes [4]. The dimension of assessment or overall evaluation of individuals about themselves, known as self-esteem, greatly determines the level of social loafing in someone [10]. According to Myers [11], self-esteem is the overall sense of self-assessment that a person uses to assess one's own characteristics and abilities. Individuals with high self-esteem will be motivated to perform as well as possible when with other people compared to individuals who have low self-esteem [9]. According to Ghufron [12], there are several factors that affect self-esteem such as gender, intelligence, individual physical condition and external factors such as social environment, school, and family. In the research conducted by Sulistiyowati in Narotama and Rustika [10], it is revealed that a person's high self-esteem will show that someone has high learning motivation. Motivation to learn is not only shown when students get assignments individually but also when they get assignments in groups, because individuals want the best possible achievement results. This indicates that someone who has high self-esteem has a low probability of experiencing social loafing.

Research conducted by Rahman [7] on 133 executives working in various organizations in Chittagong, showed that self-esteem has a negative relationship to social loafing. Positive self-esteem is important for a person to achieve the needs of life, because self-esteem can implicitly describe a person's decision on his ability to face challenges while doing a task, both individually and in groups. Self-esteem consists of feelings of worth and acceptance developed by individuals as a consequence of awareness of competence and feedback from outside oneself [13].

Based on the above analysis, the formulation of the research problem can be formulated: Is there a relationship between self-esteem and social loafing among students who are active in organizations?

\subsection{Related Work}

There is a relationship between self-esteem with social loafing on an active student organization.

A student is required to be able to master problems or be able to overcome the challenges and obstacles that will occur. One of the means self-development for students, namely by participating in organizational activities, in the organization can not be separated from the duties and responsibilities. But deep in the organization there are members who are not responsible when given the task when working as a team and not contributing to a group. Contribution each individual is expected by members of the group and in the organization.However, not a few of the group members have a tendency to spend less effort when working in groups, this is called social loafing.

Social Loafing is a decrease in motivation and effort when individuals work as a group compared when working individually. In this case, social loafing that occurs in groups will lead to tasks within the group 20 become obstructed and ineffective by the presence of social loafers. Research conducted[14], said it was wrong one cause that can influence students to do social loafing is the fear of showing that the individual is lacking understand the material or the lack of assertiveness in the individual. According to Sarwono [9], one of the factors that influence social loafing, namely someone who has low self-esteem. Individuals with self-respect height will be driven to perform as well as possible when with other people low self-esteem.

Self-esteem is the overall sense of a person's self-worth that is used to assess one's own characteristics and abilities. Self-esteem in individuals shows how an individual assesses himself [11]. According to Hidayati [14], self-esteem and social loafing have a negative correlation, students who have high self-esteem will have good interpersonal relationships and can show potential or ability possessed by contributing to a group. Meanwhile, students who have low self-esteem will reduce their abilities and do not contribute to the group.

\subsection{Our Contribution}

This research was conducted in order to provide new insights and knowledge, especially in the field of social psychology. So that later it can be used as a source of useful information for the organizational world.

Practically this research is expected to provide a deeper understanding of practical benefits, provide information for further research, and positive input for practitioners engaged in the social world. Besides that, it can also be used as a reference.

\subsection{Paper Structure}

The writing system in this study is divided into three chapters. In each chapter, there are sub-chapters. Chapter I, which is an introduction, which contains background problems regarding self-esteem with social loafing among students who are active in organizations, problem formulations, research objectives, and the benefits of research both theoretically and practically. Then in chapter II, contains the explanation of theories related to selfesteem and social loafing, the two theories explain the relationship which is then compiled a research frame of mind to produce a research hypothesis. Chapter III 
contains the research methods applied in this study. These methods include research participants, types of research, research settings and tools, research measurement tools, research procedures, and data processing and analysis techniques. Chapter IV contains main data analysis and additional data. Then the last chapter $\mathrm{V}$, which will discuss the conclusions, discussion and suggestions on this research.

\section{BACKGROUND}

\subsection{Self-Esteem}

According to Myers [11] self-esteem is the overall sense of a person's self-worth that is used to assess one's own characteristics and abilities. Individual self-esteem shows how an individual evaluates himself. Crocker and Wolfe [11] argue that individuals will have self-esteem if they feel happy with their appearance, intelligence and others consider important to the individual himself. Meanwhile, according to Devito [15], self-esteem is a person's evaluation of what they feel about themselves, and how individuals like themselves and how competent they are to judge themselves. Self-esteem is formed through individual interaction with the environment, where if the relationship provides something pleasant then self-esteem becomes positive, but if the environment provides something unpleasant, then self-esteem will be negative [16]. Self-esteem is also directed as self-worth or selfimage. An individual can feel that he is not only a human being but also a valuable human being [17].

Self-esteem is an assessment of self-efficacy, namely between the abilities that a person actually has with the ideal abilities that are expected to exist in him and will be shown through his attitude to himself, whether to accept or reject it (Brown, 1998 in [18]). Minchinton [19] says that self-esteem is an assessment or feeling about oneself based on acceptance of oneself and one's own behavior, and based on beliefs about how the individual is. This feeling of self affects how individuals relate to others around them us and other aspects of life. According to Baron \& Byrne [20] self-esteem is often measured as a level in dimensions ranging from positive to negative or high to low.

So it can be concluded that self-esteem is an assessment of the individual about who he is based on the beliefs of the individual himself. Then self-evaluations are made on each individual, people's attitudes towards themselves in a positive to negative attitude.

\subsection{Social Loafing}

Social loafing is a decrease in motivation and effort when individuals work in groups, compared to when working individually [20]. Social loafing refers to a pattern of behavior based on the fact that when several individuals work in a task that involves other people, the individual feels that he does not need to give maximum effort [21].
According to Haslam [22] social loafing is a social disease as a result of reduced responsibility towards the individual. Meanwhile, according to [11] social loafing is the tendency for people to exert less effort when individuals put together their efforts towards a common goal rather than being individually responsible. Social loafing carried out by group members will make performance in the group less effective, while for individuals, social loafing prevents individuals from getting the opportunity to develop their knowledge and abilities for the task to be done [23]. According to [24], social loafing is something that naturally occurs in students who work together for several months.

\subsection{Organization}

Hasibuan [25] said that an organization is a formal, structured, and coordinated association system of a group of people who work together to achieve certain goals. By participating in this organizational activity, students can learn to work together as a team in realizing organizational goals. According to Robbins [26] organization is a social unit that is formed consciously, with a relative boundary continuously to achieve a common goal of a place where social interaction activities are carried out or as a process where interaction occurs between people in the organization [26]

\subsection{Students}

Student is someone who is studying in college. Then students can give change and have high intellectuality, critical thinking, and are able to learn on their own in analyzing problems and learning. Students have the potential to understand developments and changes in the world of education and in the community.

According to Priambodo [27] there are several characteristics of organizational students including: (1) Individuals like to spend time participating in various activities. Students who are active in organizations tend to be involved in organizational management. (2) tend to spend more time in the organizational room just to gather, just sit around, or chat with other members. (3) students tend to have broad insight into things that happen on campus or developments in the outside world. Besides that, students are active organizations have the ability to be more sensitive and critical thinking in seeing things.

Not all students who are active in organizing have positive behavior, but as for the characteristics of students that can hinder them in an organization, these characteristics according to Ibtisam [28] are: (1) never attending a meeting, (2) as long as preparation of activities in the organization does not contribute, but at the time the event takes place individuals attend the event, (3) the responsibility given is done with other members. 


\section{METHODS}

Participants in this study have the characteristics (1) students who are actively involved in the organization or activity committee of the organization, (2) are male and female, there is no limit to gender in this study, and (3) are not there are boundaries in ethnicity, race, ethnicity and religion. This sample is all students who are currently active in the organization or activity committee of the organization as many as 407 people. Based on demographic data, it is known that the majority of subjects in this study were women (69.0\%). Term of office $6-12$ months (45.7\%), with management or position $(60.0 \%)$. This research is a quantitative research. Based on the objectives, this study is included in the correlation study. This study used a purposive sampling method, which was carried out by distributing online questionnaires using google form. The measuring instrument used in this study is the Rosenberg Self-Esteem Scale owned by Tarumanagara University, which consists of 20 statements with a 5-point Likert scale. The measuring instrument used in this study is the social loafing scale proposed by George [29]. In this measuring instrument consists of 10 statement items and a 5 point Likert scale and. both of these measuring instruments are unidimensional.

\section{FINDINGS AND DISCUSSIONS}

The author tested the assumptions using the One-Sample Kolmogorov-Smirnov Test whose results for self-esteem had an abnormal data distribution, because $\mathrm{p}=0.036$ (< 0.05). Then, the social loafing variable has an abnormal data distribution because $\mathrm{p}=0.019(<0.05)$. Furthermore, the authors conducted a correlation test to determine the relationship between self-esteem and social loafing. Correlation test using Spearman. Because, there are two variables in the study that have abnormal data distribution. The results of the Spearman correlation test found $\mathrm{r}=$ $0.307, p=0.000(<0.05)$. This shows that there is a negative correlation and significance between self-esteem and social loafing among students who are active in organizations.

The first test of difference based on gender used the MannWhitney $\mathrm{U}$ test. This test for differences in self-esteem resulted in $\mathrm{p}=0.946(>0.05)$. that there is no difference between the sexes of men and women. Whereas in the results of different social loafing tests, there were differences in the sexes of men and women which resulted in $\mathrm{p}=0.014(<0.05)$. The male gender produces a mean rank of 225.39 and women get a result of 194.41. This shows that men have a high social ranking compared to women. The results of the analysis can be seen in Table 1.

Table 1 T-Test of Self-Esteem and Social Loafing in Terms of Gender

\begin{tabular}{cccc} 
& Gender & Mean Rank & $\boldsymbol{p}$ \\
\hline \multirow{2}{*}{ Self-esteem } & Male & 204.59 & 0.946 \\
& Female & 203.73 & \\
\hline \multirow{2}{*}{ Social Loafing } & Male & 225.39 & 0.014 \\
& Female & 194.41 & \\
\hline
\end{tabular}

The second test of difference based on position / position uses the Mann-Whitney U. In this test of differences in self-esteem it produces $\mathrm{p}=0.437(>0.05)$ and social loafing which is reviewed based on position or position results in $p=0.368(>0.05)$. This shows that in the different test of self-esteem and social loafing, it shows that there is no difference in position or position held.

The three different tests of self-esteem with social loafing based on tenure, using the Kruskal-Wallis Test method, show that there is no difference in self-esteem and tenure.
Meanwhile, in social loafing there are differences in tenure. In the social loafing difference test based on the tenure, which is for 3-6 months, it produces a mean rank of 194.9, the tenure of $6-12$ months gets 221.18 and on a tenure of more than 12 months it gets 185.65 results. This shows that those with a tenure of 6-12 months have a high social level compared to those with a tenure of 3-6 months and more than 12 months. The results of the analysis can be seen in Table 2 . 
Table 2 T- Tests of Self-Esteem and Social Loafing in Terms of Tenure

\begin{tabular}{cccc}
\hline & $\begin{array}{c}\text { Tenure } \\
\text { (month) }\end{array}$ & Mean Rank & $\boldsymbol{p}$ \\
\hline \multirow{4}{*}{ Self-esteem } & $3-6$ & 200.86 & \\
& $6-12$ & 193.71 & 0.120 \\
& $>12$ & 221.23 & \\
\hline \multirow{3}{*}{ Social Loafing } & $3-6$ & & \\
& $6-12$ & 194.90 & \\
& $>12$ & 185.65 & 0.022 \\
\hline
\end{tabular}

\section{CONCLUSIONS}

Based on the results of data analysis, there is a negative and significant correlation between self-esteem and social loafing. This is in line with the opinion expressed by Sarwono, namely, there are other factors that affect social loafing, namely self-esteem. Thus, there was also no difference in social ranking with position or position. However, there are significant differences in social loafing among students who are active in organization in terms of gender and tenure.

Based on the results of data analysis using Spearman's rho. Based on the findings in this study, which has a negative relationship with self-esteem and social learning. This is in line with research from Rahman [7] which showed that self-esteem has a negative relationship with social learning. The findings of this study indicate that there are differences in social learning between women and men. After testing the variables, it was found that there was a relationship between gender and social learning in individuals. This is in line with Karau and Williams' research which states that men do more social loafing than women.

In this study, did not show any differences in social positioning in position or position. Anggraeni \& Alfian [30] said that differences in positions or positions within an organization indicate an organizational structure and division in the certainty of their roles, but when there are members who blame the essence of the position it can cause social loafing. According to Audi [31] which states that the length of time working in a group or organization can lead to social loafing.

Based on this study, the authors are aware of the limitations of the study, namely not controlling for several factors that affect social loafing. Therefore, research on social loafing needs to be studied more deeply, for further research can study it using other variables, so that it can produce interesting research. The phenomenon of social loafing often occurs in the formation of group assignments but is often not realized. Suggestions to students who are members of the organization, they should give the best contribution in the assignment and job given, have high motivation in working in groups, and when there are group members in an organization who are lazy, they will not follow it.

\section{REFERENCES}

[1] Nike, R \& Rina, M. (2006). Perbedaan penyesuaian sosial pada mahasiswa baru ditinjau dari jenis kelamin. Universitas Islam Indonesia Yogyakarta.

[2] Kurniawati, R. \& Leonardi, T. (2013). Hubungan antara metakognisi dengan prestasi akademik pada mahasiswa fakultas psikologi universitas airlangga yang aktif berorganisasi di organisasi mahasiswa tingkat fakultas. Jurnal Psikologi Pendidikan dan Perkembangan. 2(1), 17-18

[3] Luthans, Fred. (2007). Perilaku Organisasi. (Transl: Vivin A. Yuwono). Yogyakarta: Andi.

[4] Baron, R. A. \& Byrne, D. (2012). Psikologi Sosial. (10th Ed). Jakarta: Erlangga

[5] Setyawan, M. S., Erlyani, N., \& Dewi, R. S. (2016). Peranan social loafing terhadap perilaku prososial buruh perusahaan air mineral x. Jurnal Ecopsy, 3(3), 127-132. DOI: http://dx.doi.org/10.20527/ecopsy.v3i3. 2661

[6] Pratama, P. Y. S. \& Wulanyani, N. M. S. (2018). Pengaruh kuantitas, kemampuan komunikasi interpersonal, dan perilaku altruisme anggota kelompok terhadap social loafing dalam proses diskusi kelompok di fakultas kedokteran universitas udayana. Jurnal Psikologi Udayana. 5(1), 197-206

[7] Rahman, et al (2014). Understanding the Associations among emotional intelligence, selfesteem, and social loafing: An empirical study. Bup Journal, 1(2), 20-37 
[8] Chidambaram, L \& Tung, L.L. (2005). Is out of sight, out of mind? An empirical study of social loafing in technology-supported groups. Journal Information System Research, 16(2), 149-168, DOI: 10.1287/ isre1050.0051.

[9] Sarwono.(2005). Teori Teori Psikologi Sosial. Jakarta: PT.Radja Grafindo Perkasa.

[10] Narotama. I., B., Indra., \& Rustika, I., Made (2019). Peran harga diri dan efikasi diri terhadap social loafing pada mahasiswa preklinik program studi sarjana kedokteran dan profesi dokter fakultas kedokteran universitas udayana. Jurnal Psikologi Udayana, 56-67, ISSN 2654-4024. Available at: https://ojs.unud.ac.id/ index.php/psikologi/article/view/52410

[11] Myers, D. G. (2009). Social Psychology (10 $10^{\text {th }}$ Ed). McGraw-Hill

[12] Ghufron, M. N., \& Risnawita, S. R. (2010). Teori teori psikologi. Yogyakarta: Ar-ruz Media Group.

[13] Khairat, M., \& Adiyanti, MG. (2015). Self-esteem dan prestasi akademik sebagai prediktor subjective well-being remaja awal. Gadjah Mada Journal of Psychology. 1(3),180-191.

[14] Hidayati, N. (2016). Hubungan Antara Harga Diri dan Kepercayaan Diri dengan Social Loafing Pada Mahasiswa. Skripsi (diterbitkan).

[15] DeVito, J. (2011). Komunikasi Antarmanusia (5th Ed). Jakarta: Karisma Publishing group

[16] Sandha, T., Hartati, S., \& Fauziah, N. (2012). Hubungan antara harga diri dengan penyesuaian diri pada siswa tahun pertama sma krista mitra semarang. Empati: Jurnal Karya Ilmiah S1 Undip, 1(1) 47-82

[17] Dewi, F., I., R., \& Alvina, S. (2016). Pengaruh harga diri dan dukungan sosial terhadap resiliensi mahasiswa dengan pengalaman bullying di perguruan tinggi. Jurnal Psikologi Psibernetika, 9(2),156-162

[18] Anindyajati, M., \& Karima, C. M. (2004). Peran Harga Diri terhadap Asertivitas Remaja Penyalahguna Narkoba (Penelitian pada Remaja Penyalahguna Narkoba di Tempat-Tempat Rehabilitasi Penyalahguna Narkoba). Jurnal Psikologi, 2(1), 49-73.

[19] Lestari, R. dan Koentjoro. (2002). Pelatihan berpikir optimis untuk meningkatkan harga diri pelacur yang tinggal di pantai dan luar pantai sosial. Jurnal Ilmiah
[20] Baron, R.A. dan Byrne, D. (2005). Psikologi sosial. (10 $\left.{ }^{\text {th }} \mathrm{Ed}\right)$. Jakarta: Erlangga

[21] Smith, P. B. \& Bond, M. H. (1993). Social psychology across cultures: Analysis and social loafing. The Journal of Applied Psychology, 91(6), 1375-1384.

[22] Haslam, S. A. (2004). Psychology in organization: The social identity approach (2nd)

[23] Panjaitan, S. S. U., Akmal, M. E., Mirza, R. (2019). Social loafing ditinjau dari kohesivitas pada mahasiswa fakultas kesehatan masyarakat univervitas prima di Indonesia di Sumatera Utara. Jurnal Diversitas. 5(2), 76-85

[24] Price, K. H., Harrison, D. A., \& Gavin, J. H. (2006). Withholding inputs in team

[25] Hasibuan, Malayu S.P, (2011). Manajemen Sumber Daya Manusia. Jakarta: PT Bumi Askara.

[26] Praduya, M. (2017) Pengaruh aktivitas organisasi terhadap prestasi belajar studi kasus pengurus bem universitas riau kabinet inspirasi periode 2016-2017. Jurnal Online Mahasiswa Fakultas Ilmu Sosial dan Ilmu Politik Universitas Riau, 4(2) 1- 12

[27] Leny \& Suyasa, P., T., Y., S. (2006). Keaktifan Berorganisasi Dan Kompetensi Interpersonal. Jurnal phronesis, 8(1),71-99

[28] Ibtisam, F. (2018, Oktober 21). 10 ciri anak muda yang Cuma "numpang nama" di kepanitiaan dan organisasi. Diunduh dari https://rencanamu.id/post/ dunia-kuliah/unit-kegiatan-mahasiswa/10-ciri-anakmuda-yang-cuma-numpang-nama-di-kepanitiaan-danorganisasi-bisa-ketahuan-lho

[29] George, J. M. (1992). Extrinsic and intrinsic origins of perceived social loafing in organizations. Academy of Management Journal, 35(1), 191-202. DOI: https://doi.org/10.2307/256478

[30] Anggraeni, F., \& Alfian, N.I. (2015). Hubungan kohesivitas kelompok dan social loafing dalam pengerjaan tugas berkelompok pada mahasiswa psikologi universitas airlangga. Jurnal Psikologi dan Kepribadian Sosial, 4(2), 81-87

[31] Audi, N. L. (2014). Persahabatan dan toleransi pemalasan sosial pada mahasiswa psikologi universitas sumatera utara. Jurnal Pemikiran dan Penelitian Psikologi, 9(2), 52-56. 